\author{
Politics of Care and Social Responses in the July 2006 War: a Special Focus on Local Faith- \\ Based Organisations* \\ Estella Carpi
}

\title{
Abstract
}

This paper examines the politics of care of international and local humanitarian actors, as well as the social responses to their intervention in the southern suburbs of Beirut (Dahiye) during the Israeli shelling in the summer of 2006. Several faith-based and secular international NGOs and UN agencies rushed to assist individuals displaced by the Israeli air force's heavy shelling; once the large-scale violence ended, some of the international organisations that had operated in Dahiye during the war gradually turned ad hoc short-term relief into long-term development programs. This paper, through indepth interviews and ethnographic participant observation methods (2011-2013), will illustrate how short-term foreign provision of aid differs from the continuous efforts of some local providers to support their communities on a daily basis, unearth different approaches to states of emergency and responses to crisis and demonstrate how the international-local dyad plays out in a very complex way on the ground.

Keywords: Lebanon, Beirut's Southern Suburb, International Development, humanitarian aid, Aid Distribution, faith based NGOs

To cite this paper: Estella Carpi, "Politics of Care and Social Responses in the July 2006 War: a Special Focus on Local Faith-Based Organisations* ", Civil Society Knowledge Center, Lebanon Support, August, 2016 . DOI: 10.28943/CSKC.001.40004.

[ONLINE]:

https://civilsociety-centre.org/paper/politics-care-and-social-responses-july-2006-war-special-focus-localfaith-based-organisations

\section{Politics of Care and Social Responses in the July 2006 War: a Special Focus on Local Faith- Based Organisations}

\section{Introduction}

The present paper will examine the politics of care of international and local humanitarian actors, as well as the social responses to their intervention in the southern suburbs of Beirut (Dahiye) during the Israeli shelling in the summer of 2006.

Several faith-based and secular international NGOs and UN agencies rushed to assist individuals displaced by the Israeli air force's heavy shelling in areas known for having a strong Hezbollah presence. Once the large-scale violence ended, some of the international organisations who had operated in Dahiye at the time of the war gradually turned ad hoc short-term relief into long-term development programs: some of them funded new municipality services by training local staff to employ 
them in new education programs and health care, while others conducted their own programmes.

This paper, through in-depth interviews and ethnographic participant observation methods (2011-2013), will illustrate how, on the one hand, short-term foreign provision of aid differs from the continuous efforts of some local providers to support their communities on a daily basis. This contrast will unearth different approaches to states of emergency and responses to crisis. On the other hand, it will demonstrate how the international-local dyad plays out in a very complex way on the ground. The interviewed (secular and faith-based) local NGOs claim primacy in addressing domestic needs and tend to largely perceive international humanitarians as "emergency tourists". Nonetheless, people's responses, in an overall climate of disaffection towards domestic politics, reveal popular mistrust and resentment towards all aid actors indiscriminately.

In order to provide further grounds for the discussion of international and domestic programmes and Dahiye's social responses to them, this paper will assess the different politics of care, which I personally classify as Geneva-born humanitarianism "1] on the one hand, and manifold Shi'a humanitarianisms on the other. The latter falls under a diversified local humanitarianism more connected to a longstanding civilian resistance.

This paper will particularly focus on local faith-based organisations (FBOs), in relation to international and local secular aid providers. I personally interpret their service and aid provision as new forms of humanitarianism, underpinned by different philanthropic ideologies and politics of care.

Although contemporary researchers contribute to examining humanitarianism and development as increasingly interconnected and overlapping ${ }^{[2]}$, there is still a line between development and humanitarian assistance, no matter how blurred. Development - occasionally called long-term humanitarianism $^{[3]}$ in literature - tends to eradicate deep-seated problems such as inequality and poverty, and tends to cooperate with governments. Conversely, humanitarianism aims to intervene, rescue lives, and alleviate suffering. The Lebanese case proves the inappropriateness of such a distinction, not only pointing to chronic cycles of resources alternatively allocated to development and humanitarian assistance in times of emergency crisis, but also to development and humanitarian aid happening simultaneously.

\section{The controversial relationship between local and international aid providers in the aftermath of the July 2006 war}

The aid providers who worked during and after the 2006 war are international (Save the Children, CARE, Oxfam, UNICEF, Caritas, Christian Aid, Islamic Relief, USAID, Norwegian Refugee Council, Danish Refugee Council, among many others) and local NGOs (such as the secular Amel Association, Najdeh, and Samidoun Association, Hezbollah's NGOs ${ }^{[4]}$, and many other local and regional FBOs).

I primarily conducted interviews with the NGOs that worked during the July War (harb tammuz) and maintained a branch or headquarter in Dahiye in the aftermath of the war. These aid providers were all intervening in the war-stricken Beqaa Valley and in the South to a similar extent, managing shelter spaces and providing medical kits, food, mattresses, blankets, and drinkable water. The provision of aid was described by war-affected individuals as visibly sponsored with logos, posters, and signs hung 
outside of their structures. Programmes were communicated by word of mouth among the local residents. The local and international practitioners described the aid recipients' selection in 2006 as "haphazard" but "never discriminatory".

As international practitioners specified in the interviews, the previous presence of international NGOs in Lebanon was mainly due to past states of emergency. A UNDP technical advisor called NGOs operating in Lebanon "anti-governmental" organisms rather than "non-governmental", considering their minimal effort in rehabilitating the central state ${ }^{[5]}$ and rather focusing on extending their own programmes and rebuilding their own structures after emergency crises.

During this ethnographic study, it was extremely difficult to collect valuable information from the several NGOs interviewed. Their staff, mostly new, seemed to be unprepared with regard to funding sources and past projects. In other cases, the interviewees working for larger NGOs used to fear that their comments would be published to the detriment of their reputation. The fact that some NGOs deemed the topic irrelevant also pointed to a lack of interest in discussing a past emergency. Moreover, some NGO workers interpreted the research questions as an aprioristic form of judgment ${ }^{[6]}$.

The old development industry's strategy of implementing standardised projects, often regardless of local specificities, has nuanced characteristics. On the one hand, international development and humanitarian agencies increasingly rely on local providers to ensure in-depth knowledge of the addressed areas, and adopt inner perspectives to properly manage a territory of intervention. On the other, local NGOs are said to trade their own local knowledge and the access to it for financial resources and generally greater public visibility ${ }^{[7}$. In particular, for small NGOs with restricted resources, large funding allows for project evaluation - a stage that is often ruled out due to financial shortfalls ${ }^{\left[{ }^{[]}\right.}$.

In compliance with the humanitarian cornerstone of immediate alleviation of suffering, international agencies tend to prioritise emergency relief provision, which they then often transform into post-conflict development programmes. However, these longer-term projects are quickly abandoned whenever new emergencies call for urgent action and also attract funds ${ }^{9.1}$. In the Middle Eastern region, it is crucial to recall the cyclic humanitarian crises that followed the several Israeli invasions of Lebanon, most notably 1978, 1982, 1996, the 2003 American invasion of Iraq, the 2006 Israeli War on Lebanon here discussed, the 2008-2009 Israeli "Cast Lead Operation", the Syrian crisis from 2011 onwards, and the August 2014 "Operation Protective Edge" in the Gaza Strip. Needless to say that additionally, the reoccurrence of armed conflict and humanitarian need in the region has not allowed for NGOs to focus on one crisis for too long, consequently harming sustainable development.

This emergency-driven logic prompted local people to think of international aid providers - mainly from Western countries - as the sole humanitarian actors in harb tammuz. Many local residents interviewed attributed this sentiment to their perception of international aid providers as groups that capitalise on emergencies to raise funds, and that monitor Hezbollah's political movements, while not leaving any lasting impact on their beneficiaries. International humanitarian intervention has, however, been able to strengthen pre-existing channels of services for the local population, and has given rise to a new philanthropic labour market for foreign workers in Dahiye.

The international aid industry's increased reliance on local actors was easily observable in Dahiye, and 
already associated with a recent tendency of "reifying and romanticising the grassroots" international development expertise is believed to enhance local expertise, local NGOs can still utilise their networks to negotiate the implementation of projects and serve as an accessible channel for people's complaints .

In the interviews conducted, local NGOs emphasised that their partnerships with international NGOs often expose them to the risk of being blamed for failing projects, while international actors tend to specify that their mandate is restricted in Lebanon and that their action is not meant to change the societal structure. This sort of political vulnerability for local actors has yet to be considered in the old contested model of prefixed standards of development, extending beyond the relinquishment of their autonomy and the compliance with foreign financiers and "Western" elitist agendas. The endemic resistance to such risks seeks to counter the marginalisation in one's own territory ${ }^{[12]}$, sugarcoated with an increasing number of "glocal" partnerships in Lebanon.

The informality of small local NGOs in dealing with their beneficiaries often results in their low visibility within the international humanitarian sphere, as the Palestinian Association Najdeh ${ }^{[13]}$ affirmed. Such small NGOs are aware of their low visibility, and international partnerships allow local actors to gain major visibility and, consequently, funds to survive.

The increasing international reliance on local partners generally seeks to localise international organisations' projects and services, aiming to catalyse development through the already existing social forces and structures ${ }^{[14]}$. In the official discourse of international NGOs, the alliance with local NGOs is called an "exchange of ideas, skills and information" even though local partners generally described it as a unilateral process, in which the local counterpart is simply expected to adopt the "Global North's" language of development ${ }^{[15]}$. A UN agency and an international NGO representative ${ }^{[16]}$, for instance, pointed out how local counterparts would totally ignore the need for coordination without international assistance ${ }^{[17]}$. The head of a Lebanese Shi'a NGO ${ }^{[18]}$ questioned the domestic impact of the international aid industry:

"Is the humanitarian aid coming from the UN, international, and local NGOs able to catalyse social change, dialogue, and democracy, or do they reinforce the existent relations of power?"

He also stressed how the so-called international community failed in understanding that the July War was only one of the violent events in a long line of historical continuity. Resistance against destruction and humiliation supports the moral basis of the mainstream Shi'a view in which human suffering is seen as an opportunity for knowledge enhancement. As a result, the international aid industry, which mostly tackled local displacement in Dahiye, the Beqaa Valley, and South Lebanon, homogeneously victimised the war-stricken. Moreover, such a simplification is logistically necessary for the international humanitarian effort to uphold their summum bonum - as described by Plato in The Republic - which is an external and generalised perception of collective needs and a standardised "goodness" of protection and assistance ${ }^{[19]}$.

\section{Differentiating the "Shi'a humanitarian ethics" in postwar Dahiye}

In order for the suffering to end, 
you can contribute to construction and giving.

(Writing on a charity alms box in a Dahiye pastry shop)

Shi'a charity organisations ${ }^{[21]}$ knowingly represent the official ethos of Dahiye. Faith-based organisations (FBOs) played a major role in the 2006 humanitarian assistance because of their proximity to local people and their needs. According to the interviews conducted, FBOs in Lebanon are believed to be able to mobilise resources and funds with greater ease than their secular counterparts.

In particular, I interviewed the Musa as-Sadr Foundation headquartered in Tyre ${ }^{[22]}$; al-Mabarrat Association $^{[23]}$ founded by as-Saiyyd Mohammed Hussein Fadlallah - often described as the "Spiritual guide of Hezbollah" - and its sub-branch al-Hadi in the Beirut southern suburbs; and, finally, Jihad alBinaa, one of Hezbollah's largest NGOs, which is the internationally acclaimed pioneer of the Dahiye postwar reconstruction.

The charity model in Shi'a Islam has changed throughout time ${ }^{[24]}$, although this is often overlooked because religious actors, unlike the secular, tend to be viewed homogeneously and separately from other civil society actors working in the communities in which they are embedded ${ }^{[25]}$. Humanitarianism and charity are both connected to people's ideologies, reflecting theological tenets as much as social values in times of crisis and change.

In the interviews conducted with local FBOs, Islamic organisations in Lebanon represent themselves as acting on the basis of cultural and moral unity of the Muslim community - ummah - and as enhancing their autonomy by reducing dependence on Western countries' support. In general, the Shi'a local residents said they prefer referring to community services because their actions are compatible with Muslim values ${ }^{[26]}$.

Nonetheless, although local people expressed their emotional proximity to domestic community providers, the latter were simultaneously perceived as compromised by corruption and opportunism. Politicians were majorly portrayed as acting out of self-interest and political gain as much as the international humanitarian apparatus. Each actor, however, ran its campaigns on its exclusiveness in undertaking genuine humanitarian efforts. Thereby, Dahiye's public discourse, commonly known to be influenced by the political narratives of some parties, negatively portrays international humanitarian action, while paradoxically dealing with local mistrust of domestic political and humanitarian agencies.

According to the NGO classification system proposed by Clarke ${ }^{[27]}$, Dahiye's FBOs are commonly seen as socio-political because of the predominantly Shi'a population of the suburbs, allegedly reflecting the interests of a particular community. However, these FBOs promote an action agenda according to which being inclusive of non-Shi'a is a local value. The problem does not lie in their agenda being defined as confessional tout court, but rather as political. Rather, such organisations end up excluding specific local categories ${ }^{[28]}$ - the chronic poor and also Lebanese Shi'a who do not feel represented in the hegemonic civitas. This disregard has increasingly engendered disaffection towards both secular and faith-based actors.

In order to better understand local humanitarian actors, it is necessary to differentiate the ethical approach to humanitarianism at a local level. A number of Dahiye's residents contest Hezbollah's 
services and classify them as increasingly politicised and corrupt; these people, more specifically, were instead expressing melancholy when speaking of as-Saiyyd Fadlallah and his FBOs. Residents, therefore, identify themselves with the ideological principles and the politics of care of different local service providers. The variegated "Shiite way" of managing charity associations, thus, points to Fadlallah and Hezbollah as being two different spiritual and political key forces in Beirut's southern suburbs.

Both Fadlallah - following the marjaciyya ${ }^{[29]}$ doctrine - and Hezbollah have acquired increasing legitimacy from the 1980s onwards, although the two sides were initially in great disagreement with each other ${ }^{[30]}$. Nonetheless, social change and struggle against "Western imperialism" have been the cornerstones of both Hezbollah's and Fadlallah's thinking.

What an FBO worker ${ }^{[32]}$ named "Shi'a humanitarianism" is still shaped by the Shi'a cosmology of martyrdom and the struggle against injustice, symbolised by the battle at Kerbala (680 AD). Charity is in fact correlated with social justice in Dahiye and is the response to immediate needs driven by benevolent action. Justice ideals, more specifically, call for the transformation of structures that foment social injustice and indignity. For the Shi'a, Kerbala is a historically recurrent event ${ }^{[33]}$ : "In every era there is an oppressor and an oppressed. And this history always repeats itself, throughout all eras [...] People should always have the spirit of revolution against oppression". This principle constitutes the bedrock of the Shi'a mobilisation in Lebanon (taba'iya) ${ }^{[34]}$.

As such, Shi'a humanitarianism has not merely served as a political strategy to turn public compassion into political consent ${ }^{\text {[35] }}$, as Islamic philanthropy has often been reduced to "machiavellism". Rather, it has come to form a constitutive part of social assistance. Humanitarianism does not necessarily need to be implemented only in response to the Israeli occupation, but rather in response to any injustice, including poverty and lack of education. The chronic uncertainty according to which the Shi'a religious community has developed its own conceptions of life is inherent to the existential approach underlying Shi'a humanitarianism, both in wartime and in peacetime ${ }^{[36]}$. Likewise, public activism and social engagement are the way religious people strive to continue to live the 'Ashura ceremony on a daily basis.

Similarly, volunteerism and employment are seen as contributions to the development of the whole Shi'a community. Working for a welfare organisation means to bring Zeinab ${ }^{[37]}$, a holy figure in Shi'a theology, into the present ${ }^{383]}$. Thus, the common ethical judgment easily identifiable in academic literature ${ }^{[39]}$ on Islamic organisations completely overlooks the fact that these NGOs do not merely use Islamic values and charity for political interests, but that they simply are Islamic. In fact, humanitarian intervention is locally perceived as less opportunistic when concerning local providers that have long since provided assistance to the victims of cyclic displacement in Dahiye. The aforementioned emergency-driven logic of the international aid industry has evidently not been adopted by their Shi'a counterparts in harb tammuz or in its aftermath. Indeed, when Syrian refugees began pouring into Dahiye during the current Syrian crisis, the political agenda of these Shi'a organisations reflecting Iran's ideology in Lebanon only to a certain extent - certainly does not deal with Syrians as refugees, or, in other words, as victims of political repression deserving assistance. The interviewed Shi'a organisations in Dahiye emphasised that they would rather guarantee assistance both in wartime and in peacetime, boasting technical and infrastructural self-confidence, despite highlighting that 
Christian services are more developed for historical reasons ${ }^{[40]}$.

Nonetheless, the local perception of local FBOs was ambivalent. On the one hand, they were seen as rarely addressing chronic poverty and local injustice, just like international organisations: "They often end up feeding the accountability of the political party that supports them and promotes them", recounted Mohammed, a local resident of Dahiye ${ }^{[4]]}$. On the other hand, while international humanitarian NGOs tend to view beneficiaries as victims of man-made crises - and therefore as morally deserving individuals and rights bearers that need to be protected - Fadlallah's and Hezbollah's services have been able to make people feel like political agents ${ }^{[42]}$ - i.e. resistant, and, although usually laden with antipathy towards the central state, still de facto citizens rather than objects of charity. Social mindfulness and independence are seen as the key qualities needed to become complete individuals, thus demonstrating the proactive function of human life from the Shi'a humanitarian perspective ${ }^{[43]}$.

The organisations created by Fadlallah that were interviewed contended that their Shi'a ideology is closer than other Shi'a counterparts to the secular conception of humanitarianism, as it is conceived as a homogeneous force aimed at alleviating and comforting human suffering. These FBOs have, however, a specific project to pursue, which implies the idea of a civilian - rather than merely Islamic resistance. For example, in the fundraising campaigns of Fadlallah's associations, Israel is mentioned as the agent of destruction in expressions such as, "Our organisation was destroyed by Israel. We will continue, more committed to doing good". The very reason behind human life is identified with the moral commitment to be doing good.

Moreover, in al-Mabarrat Association's ideology, "doing good" explicitly means to guide individuals ${ }^{[4]]}$, and constitutes the only possible form of humanitarianism. Such explicitness is banned in the Genevaborn international aid provision, which does not officially aim to provide guidance. Similar to Fadlallah's approach, the philanthropic heirs of Imam as-Sadr contribute to a local humanitarian language, which is close to charity. Even though some scholars ${ }^{45]}$ mention the divergences between these two key Shiite figures, Fadlallah and Sadr both represented the "emerging breed of Shiite revivalists in Lebanon", the former being a good connection to the transnationalism with Iran, and the latter providing a Lebanese component of Shiite political Islam.

Unlike Fadlallah's FBOs, however, according to Maliha as-Sadr ${ }^{[47]}$, humanitarianism should trigger empowerment by making continuous efforts and equalising Lebanese society ${ }^{[48]}$. She highlighted how different the Shi'a notion of humanitarianism is from the Geneva-born, which is depicted as caring about longer-term sustainability only in the wake of emergency crises. Also, local FBOs, in her view, cannot and should not aim to dismantle themselves, which is what some international humanitarian agencies find to be their ideal, once domestic sustainability is reached ${ }^{[49]}$. Providing and benefiting from social services within Dahiye's local community is in fact part of their struggle against Israel, it is "not a war to kill, but a war for the right to exist" ".50] . Development efforts and social assistance in this context are a way of coping with chronic uncertainty, and hope policies allow the community to have a link with the future, where hope evolves from a mere emotion into a conscious and realistic proposition. In a nutshell, social efficiency and mutual care deal positively with recurrent exposure to war.

Fadlallah-founded al-Mabarrat also highlighted their readiness to work with foreign NGOs and universities: "Such openness is not always well accepted in Dahiye [...] and it is often labeled as mere 
commodification" ${ }^{,[51]}$. In this regard, the tendency not to rely on external actors also depends on whether or not their strategies and agendas will meet local needs. In this regard, the Deputy Mayor of Haret Hreik Hajj Hatoum ${ }^{[52]}$ said that, overall, international donors in harb tammuz rarely grasped what the local priorities were:

"Their main focus has been providing psychological assistance. [...] That was not really the issue. We had apartments totally destroyed, damaged buildings, women needing specific help. So, the problem with cooperation with international providers is that they don't fund and work for the things we really need. The reality is never changed by humanitarian services, but if you want to give something, help with infrastructure and provide money for housing and furniture. From outside, little money came with this purpose".

Al-Mabarrat's staff, by contrast, argued that they viewed themselves as a segment of the international aid structure.

Some local discontent with international organisations, however, is also present in the area. The manager of the Research and Development Department at the Imam as-Sadr Foundation ${ }^{[53]}$, for example, questioned the paths undertaken by all NGOs in Lebanon, which, in his opinion, are very outcome-oriented. In this regard, he affirmed: "it is much easier to assess the material results of a project. The change promoted by an NGO comes from the process, more than from its material results" ${ }^{,[54]}$. Projects conducted by international agencies, sometimes in partnership with local NGOs, are too often unable to grasp what sort of social processes for enhancement should be triggered within local society and, therefore, unsure how to set goals within a specific project. The continuation of such collaborations, in his opinion, is only due to matters of Realpolitik, since Lebanese NGOs need international visibility and the international providers primarily show up in times of emergency ${ }^{[55]}$.

Hence, the Shiite provision of services and aid is largely hybrid. Notably, Hezbollah's Fadlallahfounded services, and the Sadr Foundation differ in their approach to the humanitarian outside. Both promote a community-crossing vision of Dahiye, arguing for services to be provided for any Lebanese community. Nevertheless, it is generally recognised that few people from non-Shi'a communities are able to access their services, owing to the demographic changes that occurred in Lebanon in the immediate aftermath of the civil war (1989-90). For instance, the mentioned Imam as-Sadr Foundation, created in the 1960s prior to the civil war and described ${ }^{[56]}$ as associate to Fadlallah's approach despite the sporadic competition between each other as FBOs - "used to address anyone in the South, where Christian Maronites, Christian Orthodox, and Armenian Catholics were far more numerous" ${ }^{\text {"[57] }}$.

FBOs founded by Hezbollah, during and after harb tammuz, turned their programmes into compensation strategies for any community inhabiting Dahiye. Through its communication channels, the political party highlighted the domestic nature of the reconstruction, and that people's return to their own houses was a victory achieved by local individuals and made feasible by their own hands ${ }^{[5]}$. The "victory narrative", however, was also adopted by secular local providers"

Unlike Fadlallah's approach to aid provision, a local secular $\mathrm{NGO}^{[60]}$ spoke of the necessity of cultivating responsibility in Lebanon by charging the beneficiaries for the required services when feasible, with the intent of not providing charity aprioristically. It is in this sense that they argued that they are "the feet 
and not the head of [their] own society". The morals of guiding individuals, typical of Fadlallah-founded associations, are lost here. Local secular NGOs generally defined their own work in terms of catalysation of an active and dynamic civic sense already existing within the country. However, in some cases, NGOs deny their political influence on society by delegating politics to the local people. From this perspective, NGOs simply accelerate and support people's actions, and transform common people's ideas and intentions into real changes. In this regard, the head of Amel Association, Kamel Mohanna ${ }^{[61]}$ argued that his NGO's work merely consists of promoting a "culture of rights" - thaqafat alhuquq - which, in current Lebanese society, tends to be rather community-oriented.

By reconciling the secular and the "Shi'a" perspectives, with all due endemic diversifications, Zahir Jalul $^{[62]}$ emphasised the importance of a culture of humanity - thaqafat al-insan - that is still absent in Lebanon. However, the locally reformulated conception of humanitarianism, international-oriented on its surface, is still historically marked by the blood shed by martyrs ${ }^{[63]}$ as well as the individual commitment in the Resistance.

\section{Heterogeneous local aid provision: beyond the secular-religious binary}

The local perspectives of humanitarian assistance at the time of harb tammuz also differed from each other. Many informal and generally small organisations were set up by local residents. For instance, some of Dahiye's businessmen whom I met, constituting the newly emerged Shi'a middle class, began distributing clothes, furniture accessories and money to the socially vulnerable "for the Islamic value of doing charity, as it's written in the Holy Koran", as Hasan, a Lebanese businessman, affirmed in Haret Hreik $^{[64]}$. "Of course there are people who became homeless in the July War, but orphans are always around in Dahiye. You always have a reason to help, until the time these people will be able to empower themselves" [for the sake of precision, Hasan uses the Arabic expression yaksab ajar alma'ida, meaning until the time one is able to "earn his own living"]. This phenomenon gave rise to a sort of private proliferation of services in the form of organic cultural expressions and religious obligations after harb tammuz: a war that redefined the social strata of the war-stricken areas, and that later empowered some and impoverished others. Mixed economies of laissez-faire inhabit the public space in an aiding-purchasing-selling chain ${ }^{[65]}$ in which subsidies and charity services target only the very poor without a broad plan to generate long-term sustainability.

The fact that the Lebanese state ceded welfare to the local religious domain encouraged the colonisation of the public by the private in Lebanon ${ }^{[66]}$. In turn, charity and local entrepreneurship can be reconciled, although pursued by actors with different conceptions of humanitarianism and philanthropy. Hasan regarded the local Shi'a conception of charity as a way of cleansing his own privilege of being a self-enfranchised and established large-scale seller, politically well connected with the Hezbollah party. This notion and rationale of help was shared among other Lebanese Shi'a businessmen who I met in Dahiye.

If secular aid provision cannot really be universal, this also occurs with religious care provision, which in practice tends to address community members. The community belonging, in this case, is rhetorically marked as the core of the philanthropic act of provision and assistance. Like the secular, it also implies the risk of establishing moral hierarchies between recipients and providers. For instance, a social worker (of religion "y") working for a local FBO and having assisted the displaced in 2006 in ash- 
Shiyyah, claimed how easy and quick it was to become of religion "z", and therefore become entitled to service provision $^{[67]}$ :

'... ' $z$ ' are all used to taking, whereas, as a ' $y$ ', I'm used to giving. That's so much easier to be ' $z$ ' [...] If a ' $z$ ' asks for something, he doesn't lose prestige and dignity, unlike us [' $y$ ']. To take and ask is the nature of their faith... I mean, the people you see in some areas to some extent want to be poor, or they wouldn't get any help otherwise" ${ }^{, 168]}$.

The giving-taking binary here seems to unfold biased individual conceptions of a particular faith and points to the moral status which a confessional group holds within one's own social pyramid. In other words, service and aid provision problematically came to constitute a fundamental tile in the "moral economy" of local communities.

In times of emergency, however, a large number of social workers, who normally view service provision as a matter of community belonging and cultural inheritance, particularly tend to renew their collective sense of belonging and a greater wanting to help. According to the vast majority of the interviewees, as long as the Lebanese government does not empower anyone, "religious providers are more than welcome [to meet] people's needs" that, after 2006, Dahiye became an increasingly self-sufficient space as it also became an important commercial hub for the Greater Beirut area, where symptoms of a "damaged identity" , including the fears of erasure, displacement, and marginalisation disappeared. In this sense, religion-based philanthropy vests the services provided with a specific moral aura. The religious importance of guiding the vulnerable towards self-empowerment differs from the local efforts - defined as "secular" in official discourses - of limiting intervention to supporting pre-existing forms of civil action.

\section{Conclusion}

Faith-based and secular non-state providers in Dahiye provide social services to strengthen the social safety nets that the Lebanese state has been unable to weave ${ }^{[12]}$. Nevertheless, the communityoriented social provision of services, as much as the secular, proved to have power implications within the social moral hierarchy.

Dahiye is not a uniform space to be healed, as it has frequently been stereotyped from outside. In fact, the southern suburbs of the Lebanese capital nowadays constitute a special urban case, where local political power, chronic poverty, cyclical destruction and reconstruction occur simultaneously, raising the importance of a more fluid reconceptualisation of social vulnerability.

While both international and local provision of aid have revealed their complexities and diversification on the ground, the ad hoc approach of the Geneva-born humanitarian apparatus to crisis management was locally perceived as mostly touristic, and the outside interest in these war-affected areas as voyeuristic. As earlier discussed, this contrasts with the daily attempt of local organisations to cope with continuous hardships disconnected from regional political violence and from humanitarian crises, which rarely interests foreign political agendas.

Local social work and the relief provision for co-residents in times of conflict finally had the role of 
intensifying people's attachment to Dahiye and their territorial ownership.

Nevertheless, this paper does not want to suggest that international and local (especially FBOs) are embedded in a sterile antagonism. Over the Syrian refugee influx in Lebanon, UN agencies - especially UNDP - promoted cooperation and coordination with local and international FBOs, pointing to the lessons learnt in the years before. ${ }^{[1] 3]}$ Thereby, international development agencies and the humanitarian afflatus attempt to find their own place as technocrats within the social fabric of domestic charity work, which, in Lebanon's history, is mostly faith-based or community-oriented.

Thus, on the one hand, international ad hoc emergency relief increasingly turns into long-term aid provision, addressing chronic vulnerabilities. On the other hand, local charity endeavours give rise to a new form of giving to one's own community in times of emergency, when alleviation of suffering and meeting essential needs come first. During crises, hence, such local charity organisations increasingly intertwine with international humanitarian assistance and development programmes, diversifying the way faith can be put into action. At the same time, actors of local governance accept funding from international donors to strengthen service provision.

In this framework, not only international humanitarianism, which rushes over in times of crisis, becomes an arm of mobile governance; but also some local providers considerably reformulate their philanthropic agendas by recognising international assistance as a good teacher of capacity building and fundraising. Nonetheless, local aid organisations also reclaim technocracy and territorial ownership, feeding into ordinary people's resentment in Dahiye towards the "touristic" approach of international (and traditionally neutral) humanitarianism. To what extent international humanitarian intervention is made conditional on the basis of local needs and domestic politics agendas remains contextual and debatable.

Aid and service providers increasingly become long-term development technocrats and life rescuers during crises, in both local and international NGOs, leaving ground for complex and flexible collaborations. Nevertheless, my ethnographic experience in Dahiye has unraveled how the Genevaborn assistance, "rescuing" and "healing" emergency-affected subjects, poorly fits the local context; in which local FBOs rather interpret emergencies as a historical continuum and as the last straw of prolonged unjust deprivation. The politics of reclaiming the agency of the suffering subjects, which is usually known as international participatory development, suggests new forms of local secular and religious humanitarianisms, detached from passive victimhood.

While the interplay of these different aid actors in harb tammuz was not within the primary scope of research at the time of the fieldwork, this paper has sought to unravel different politics of care and approaches to emergencies, especially of local charities, in addition to the ways in which heterogeneous philosophies of action influence social responses. Further analysing the ethical approach of all these different actors to help and care may take us to new and unexpected research avenues. And that will probably be the task of secularism and religion scholars.

*This paper is published in the frame of the call for papers Glocalizing humanitarian interventions in Lebanon: a reflexive look into innovative practices in times of crises developed by Lebanon Support and Amel Association. 


\section{Bibliography}

Erik Abild, Hezbollah. A Contextual Study focusing on Human Freedom, BA Thesis in Development Studies, University of Oslo, 2007.

Arun Agrawal and Kalyanakrishnan Sivaramakrishnan (eds), Agrarian environments. In Social Nature: Resources, Representations, and Rule in India, New Delhi, India, Oxford University Press, 2001, p. $1-22$.

Fouad Ajami, The Vanished Imam. Musa al-Sadr and the Shi'a of Lebanon, New York, Cornell University Press, 2012.

Estella Carpi, Adhocratic Humanitarianisms and Ageing Emergencies in Lebanon: from the July 2006 War in Beirut's Southern Suburbs to the Syrian Refugee Influx in Akkar's Villages, PhD Thesis, University of Sydney (Australia), 2015.

Gerard Clarke and Michael Jennings, Development, Civil Society and Fatih-Based Organisations. Bridging the Sacred and the Secular, London, UK, Palgrave Macmillan, 2008.

Lara Deeb, "Emulating and/or embodying the ideal. The gendering of temporal frameworks and Islamic role models in Shi'a Lebanon", American Ethnologist, Vol. 36, No.2, 2009, p. 242-257.

Didier Fassin and Richard Rechtman, The Empire of Trauma. An Inquiry into the Condition of Victimhood, Princeton, NJ, Princeton University Press, 2009.

Didier Fassin, “Les économies morales revisitées”, Annales HSS No. 6, 1237-1266, 2009.

Mona Fawaz, "Agency and ideology in Community Services: Islamic NGOs in the Southern Suburbs of Beirut", in (eds.) Sarah Ben-Nefissa, Nabil 'Abd al-Fattah, Sari Hanafi, and Carlos Milani, NGOs and Governance in the Arab World, Cairo, Egypt, AUC Press, 2005, pp. 229-256.

Nell Gabiam, "When 'Humanitarianism' Becomes 'Development': The Politics of International Aid in Syria's Palestinian Refugee Camps”, American Anthropologist No. 114, Vol. 1, 2012, pp. 95-107.

Joshua L. Gleis and Benedetta Berti, Hezbollah and Hamas: A Comparative Study, Baltimore, MD, JHU Press, 2012.

Adam Hanieh, "Shifting Priorities or Business as Usual? Continuity and Change in the post-2011 IMF and World Bank Engagement with Tunisia, Morocco and Egypt", British Journal of Middle Eastern Studies, Vol. 42, No. 1, 2015, pp. 119-134.

Mona Harb, Le Hezbollah à Beirut (1985-2005): de la Banlieue à la Ville, Paris, France, IFPO-Karthala, 2010.

Rana Jawad, "Religion and Social Welfare in the Lebanon: treating the Causes or Symptoms of 
Poverty?", Journal of Social Policy, No. 38, 2009, pp. 141-156.

Samir Khalaf, Heart of Beirut: reclaiming the Bourj, London, UK, Saqi Books, 2006.

Saree Makdisi, "Laying Claim to Beirut: Urban Narrative and Spatial Identity in the Age of Solidère", Critical Inquiry, Vol. 23, No. 3, 1997, pp. 664-705.

Farah el-Jam Makkouk, Assessment of Airborne Particulate Matter Elevation in Haret Hreik (Beirut) after the Israeli Bombardment of July 2006, MA Thesis, Beirut, Lebanon, AUB, 2008.

Duncan McDuie-Ra and John A. Rees, "Religious Actors, Civil Society and the Development Agenda: the Dynamics of Inclusion and Exclusion", Journal of International Development, No. 22, 2010, p. 20-36.

Ashis Nandy, Time Warps: The Insistent Politics of Silent and Evasive Pasts, London, UK, Hurst and Company, 2002.

Ananya Roy, "Civic Governmentality: the Politics of Inclusion in Beirut and Mumbai", Antipode, Berkeley, California, University of California, 2008, pp. 7-10.

Amal Saad, An Analysis of the Factors conducive to the Group Cohesion and Political Mobilization of the Lebanese Shiites, MA Thesis, Beirut, Lebanon, American University of Beirut, 1996.

UNDP, Guidelines on Engaging with Faith-Based Organizations and Religious Leaders, October 2014, available at:

http://www.undp.org/content/dam/undp/documents/partners/2014_UNDP Guidelines-on-Engaging-withFBOs-and-Religious-Leaders_EN.pdf [Last accessed July 14, 2016].

Leila Zakharia and Sonya Knox, The International Aid Community and Local Actors: Experiences and Testimonies from the Ground, the Civil Society Knowledge Centre, 2014, Lebanon Support, available at: https://civilsociety-centre.org/paper/international-aid-community-and-local-actors-experiences-andtestimonies-ground [Last accessed: June 16 2014].

"Emergency humanitarianism is considered to have burgeoned in Geneva, which is the city that Henry Dunant, founder of the Red Cross in the $19^{\text {th }}$ century, came from. By Geneva-born humanitarianism I therefore refer to ad hoc assistance of crisis-stricken and displaced people in times of emergency crisis, and in compliance with the principles of neutrality and impartiality.

${ }^{[2]}$ Nell Gabiam, "When 'Humanitarianism' Becomes 'Development': The Politics of International Aid in 
Syria's Palestinian Refugee Camps", American Anthropologist No. 114, Vol. 1, 95-107, 2012; Estella Carpi, Adhocratic Humanitarianisms and Ageing Emergencies in Lebanon: from the July 2006 War in Beirut's Southern Suburbs to the Syrian Refugee Influx in Akkar's Villages, PhD Thesis, University of Sydney (Australia), 2015.

${ }^{[3]}$ Anthropologist llana Feldman engages with this concept in all of her work.

${ }^{[4]}$ Specifically, al-Jarih for the war wounded; ash-Shahid for the families of the war victims; al-Imdad for local development and social welfare; al-Qard al-Hasan for provision of microcredit to local families; alHa'iya as-Sahhiya al-Islamiyya for health assistance and protection.

[5] Interview conducted by the author with the coordination officer of UNDP, Beirut Downtown, October 25,2011 . This shows the particular task that humanitarianism seems to have in Lebanon: maintaining order and alleviating war plagues, certainly not reforming the state.

[6] Also, some NGO workers tended to adopt a critical perspective just when we used to meet outside of their office. The information I was able to collect was much more substantial in those circumstances.

${ }^{[7}$ Leila Zakharia and Sonya Knox, The International Aid Community and Local Actors: Experiences and Testimonies from the Ground, the Civil Society Knowledge Centre, 2014, Lebanon Support, available at: https://civilsociety-centre.org/paper/international-aid-community-and-local-actors-experiences-andtestimonies-ground [Last accessed: June 16 2014]. 
[8] The head of an Italian NGO confirmed that the stage of project evaluation is often ruled out in small international NGOs. Interview conducted in Beirut, October 25, 2011.

[9] It is worth specifying that the differentiation of experiences contributes to the upgrading of the NGO workers' career. Indeed, emergency complexes tend to create further spheres of professionalisation in Lebanon and elsewhere for internationals and local middle and upper classes (Adam Hanieh, "Shifting Priorities or Business as Usual? Continuity and Change in the post-2011 IMF and World Bank Engagement with Tunisia, Morocco and Egypt", British Journal of Middle Eastern Studies, Vol. 42, No. 1, 2015, pp. 119-134).

${ }^{[10]}$ Arun Agrawal and Kalyanakrishnan Sivaramakrishnan (eds), Agrarian environments. In Social Nature: Resources, Representations, and Rule in India, New Delhi, India, Oxford University Press, 2001, p. 12.

${ }^{[11]}$ For instance, the UNDP approach proposed the institution of working groups with different competences, and certainly not the consideration of individual needs, "...As this would be populism, which is deleterious". Interview with the UNDP technical advisor, Beirut Downtown, October 25, 2011.

${ }^{[12]}$ Duncan McDuie-Ra and John A. Rees, "Religious Actors, Civil Society and the Development Agenda: the Dynamics of Inclusion and Exclusion", Journal of International Development, No. 22, 2010, p. 25.

${ }^{[13]}$ Interview conducted in Borj al-Barajneh, November 13, 2011. 
${ }^{[14]}$ This is a common argument that emerged in the interviews and was voiced in the interviews with Amel Association, Oxfam Italia, and CTM-Lecce (Wata al-Mossaitbeh, Beirut, October 11, 2011; Forn ash-Shebbak, October 18, 2011; al-Jemmaiyze, Beirut, October 25, 2011). Indeed, humanitarianism, from Amel Association's perspective, was defined as a construction of civil society networks. "The motto should be: national unity and humanitarian solidarity", said Mr Kamel Mohanna, October 11, 2011. Also, the humanitarian was specified as transcending the political and the confessional.

${ }^{[15]}$ Leila Zakharia and Sonya Knox, The International Aid Community and Local Actors: Experiences and Testimonies from the Ground, the Civil Society Knowledge Centre, 2014, Lebanon Support, available at: https://civilsociety-centre.org/paper/international-aid-community-and-local-actors-experiences-andtestimonies-ground. [Last accessed June 16 2014].

[16] Beirut, October 2011.

${ }^{[17]}$ For some of the interviewees, high levels of coordination are impossible. "Overlaps are kind of unavoidable when you work in a very small country", Head of an Italian NGO, Beirut, October 25, 2011. In other cases, coordination is instead seen as unadvisable: "We never coordinate with other NGOs, particularly the international, because we don't want to adapt our projects to foreign aims, and we don't want to be conditioned from outside" (Interview with a Lebanese humanitarian agency, Spears, Beirut, February 1, 2012).

${ }^{[18]}$ Tyre, October 8, 2012.

[19] Didier Fassin and Richard Rechtman, The Empire of Trauma. An Inquiry into the Condition of Victimhood, Princeton, NJ, Princeton University Press, 2009. 
${ }^{[20]}$ Translation from Classical Arabic conducted by the author.

[21] I will use the definition of "faith-based" to refer to NGOs inspired by specific confessional principles in laying out their implementation strategies, although faith is only one facet of a broader religious identity, which eventually belongs to a social order. Jawad decides to classify these NGOs as "religious welfare" (Rana Jawad, "Religion and Social Welfare in the Lebanon: treating the Causes or Symptoms of Poverty?", Journal of Social Policy, No. 38, 2009, pp. 141-156). Nandy instead differentiates between religion as "ideology", a (sub)national identifier of populations protecting socio-economic or political interests, and religion as "faith, a way of life, a tradition that is definitely non-monolithic and operationally plural" (Ashis Nandy, Time Warps: The Insistent Politics of Silent and Evasive Pasts, London, UK, Hurst and Company, 2002, pp. 61-62). Indeed, states prefer to deal with religions as faiths rather than ideologies.

[22] The Musa as-Sadr Foundation in fact had just built a new branch in Dahiye.

${ }^{[23]}$ Fadlallah founded al-Mabarrat Association in 1978 to provide a library, education services for orphans, a hospital mosque, and a dispensary. Not all of these facilities were funded by Iran as often believed (Mona Harb, Le Hezbollah à Beirut (1985-2005): de la Banlieue à la Ville, Paris, France, IFPOKarthala, 2010, pp. 45-46); they had been set up with the purpose of enabling people to engage in social activities and actions, on the conceptual basis of employing al-multazimun ("committed people"). Fadlallah, known for having issued quite modernistic fatwas at al-Hassaneiyyn Mosque in Haret Hreik, also used to hold a phone line where anonymous people could call and ask for consultancy about daily Muslim practices.

${ }^{[24]}$ Rana Jawad, "Religion and Social Welfare in the Lebanon: treating the Causes or Symptoms of 
Poverty?", Journal of Social Policy, No. 38, 2009, pp. 141-156.

${ }^{[25]}$ Duncan McDuie-Ra and John A. Rees, "Religious Actors, Civil Society and the Development Agenda: the Dynamics of Inclusion and Exclusion", Journal of International Development, No. 22, 2010, p. 21.

${ }^{[26]}$ This paves the way for reflection altogether with the words of the director of Waqf Taiba, a Saudi NGO in Akkar: "It is important to protect the village from Western ideologies". Interview conducted in Halba, Akkar. December 14, 2012.

${ }^{[27]}$ Gerard Clarke and Michael Jennings, Development, Civil Society and Fatih-Based Organisations. Bridging the Sacred and the Secular, London, UK, Palgrave Macmillan, 2008.

[28] Mona Fawaz, "Agency and ideology in Community Services: Islamic NGOs in the Southern Suburbs of Beirut", in (eds.) Sarah Ben-Nefissa, Nabil 'Abd al-Fattah, Sari Hanafi, and Carlos Milani, NGOs and Governance in the Arab World, Cairo, Egypt, AUC Press, 2005, pp. 229-256.

${ }^{[29]}$ A marja'iyya is a religious Shia institution: Hezbollah independently follows the Khomeini doctrine under the Wilayat al-Faqih, which represents the fusion between the religious and the political, and leads the Twelver Shi'a community till the end of all eras, when the 12th hidden Mahdi-sahib azzaman, the "Patron of Time" - will come back to liberate the Shi'a from oppression once and for all. 
${ }^{[30]}$ Vandalistic acts against Fadlallah's properties, in fact, occurred in the southern suburbs of Beirut, prior to the Shi'a cleric's good relationship with the Party of God. The latter was accused of having committed the wrongdoing. Fadlallah was considered an ideologue and the spiritual guide of Hezbollah towards the end of his life after dissolving past frictions (Mona Harb, Le Hezbollah à Beirut (1985-2005): de la Banlieue à la Ville, Paris, France, IFPO-Karthala, 2010, p. 44).

[3.1] Such political orientations caused an attempt of assassination of the Shi'a cleric on March 8, 1985 in Bi'r al-'Abed (Dahiye), conducted by the C.I.A in the framework of the American "preemption" counterterror program. The exploded car bomb caused 80 casualties and 200 wounded.

${ }^{[32]}$ Interview conducted by the author in Bi'r Hasan, Beirut, 19 November 2013.

${ }^{[33]}$ Lara Deeb, "Emulating and/or embodying the ideal. The gendering of temporal frameworks and Islamic role models in Shi'a Lebanon", American Ethnologist, Vol. 36, No.2, 2009, p. 247.

${ }^{[34]}$ Amal Saad, An Analysis of the Factors conducive to the Group Cohesion and Political Mobilization of the Lebanese Shi'a, MA Thesis, Beirut, Lebanon, American University of Beirut, 1996.

${ }^{[35]}$ Ananya Roy, "Civic Governmentality: the Politics of Inclusion in Beirut and Mumbai", Antipode, Berkeley, CA: University of California, 2008, pp. 7-10. 
${ }^{[36]}$ Anthropologist Lara Deeb (Lara Deeb, "Emulating and/or embodying the ideal. The gendering of temporal frameworks and Islamic role models in Shi'a Lebanon", American Ethnologist, Vol. 36, No.2, 2009, pp. 242-257) pointed out how Iranian mahdism implies a greater escatological logic than in Lebanon. The Last Day belief is less mentioned by Lebanese Shi'a and, as a consequence, less representative of local mentality, given that, in the case of Lebanon, this theology is not a hegemonic state plan, but rather a political party's strategy or culture. Only one among others.

${ }^{[37]}$ It is worth getting deeper into the Zeinab figure as a source for inspiration: women activists, however, cannot equate her. The way Lebanese Shi'a women look at this figure is therefore induced by social circumstances, which are different from Iran. This leads to a theoretical dissent about the Weberian conviction that religion is a key factor in influencing reality. Furthermore, the preaching of Imam Mohammed Fadlallah - called marii' at-taqlid (the "point of reference for tradition") - widely contributed to the empowerment of women in terms of religious roles: he used to say that women can attain the highest level of jurisprudential training and interpret religious tenets, despite the absence of such a norm in Shi'a jurisprudence (Lara Deeb, "Emulating and/or embodying the ideal. The gendering of temporal frameworks and Islamic role models in Shi'a Lebanon", American Ethnologist, Vol. 36, No.2, p. 251). Even so, the normative moral womanhood was majorly represented by Fatima, a model of calm, maternalism and patience, in opposition to the westernised women in Iran in 1971, as specified by Iranian scholar 'Ali Shari'ati. In that frame, women were called to actively participate in political life only during moments of crisis, and this implied a changing gender role for women in daily life, with respect to the more static figure of Hussein, who epitomises the inspirational model for Shi'a manhood.

${ }^{[38]}$ Lara Deeb, "Emulating and/or embodying the ideal. The gendering of temporal frameworks and Islamic role models in Shi'a Lebanon”, American Ethnologist, Vol. 36, No.2, 2009, p. 250.

${ }^{[39]}$ Fouad Ajami, The Vanished Imam. Musa al-Sadr and the Shia of Lebanon, New York, Cornell University Press, 2012.

${ }^{[40]}$ Interview with Mr Faruq Rizq, al-Mabarrat headquarter, al-Ghobeiry, Beirut, October 18, 2012. 
${ }^{[41]}$ Interview with Mohammed, a local shop owner, Haret Hreik, February 2, 2012.

${ }^{421}$ This also occurs as the provider-recipient relationship is based on a social contract or reciprocity in Dahiye. The politicisation of services, therefore, merely expresses the already existing moral and social relationships between the two parts. In particular, during Lebanon's civil war, Fadlallah used to speak up for the necessity of creating a "human state" - dawlat al-insan - that would provide the resources for people to help themselves and one another. He was known for considering public funds as ownership of the people and for capturing this ethics when he said that he was not looking for "followers" but "partners" (Ken Silverstein, Hezbollah's Strength derives from the Strong Social Fabric that they have woven over the years, 2007, available at:

http://newsgroups.derkeiler.com/Archive/Soc/soc.culture.iranian/2007-03/msg01663.html [Last accessed October 3 2011]. It is this specific political logic which allowed the Hezbollah party to foster its politics of inclusion.

${ }^{[43]}$ Interview with Mr Faruq Rizq, al-Mabarrat headquarter, al-Ghobeiry, Beirut, October 18, 2012.

${ }^{[44]}$ Interview with al-Hadi Association (al-Mabarrat's branch), Tariq al-Matar, Beirut, October 29, 2012.

${ }^{[45]}$ Fouad Ajami, The Vanished Imam: Musa al-Sadr and the Shi'a in Lebanon, New York, Cornell University Press, 2012. 
${ }^{[46]}$ Joshua L. Gleis and Benedetta Berti, Hezbollah and Hamas: A Comparative Study, Baltimore, MD, JHU Press, 2012.

[47]

Interview with Ms Maliha as-Sadr, Imam as-Sadr Foundation, Ouzai, Beirut, December 4, 2012.

${ }^{[48]}$ Mr Mohammed Bassam, for instance, said that at the Imam as-Sadr Foundation the use of hishma at school is obligatory (the "decent" school uniform used to homologate social classes and discipline the dress code in their institutions).

${ }^{[49]}$ Conversely, some INGOs act instead on the basis of cooperation efforts, which do not imply the dismantlement of the structure in the territory of intervention, but rather aim to further mutual assistance and knowledge exchange between different countries (Interview with the head of an Italian NGO. Beirut, February, 2013).

${ }^{[50]}$ Erik Abild, Hezbollah. A Contextual Study focusing on Human Freedom, BA Thesis in Development Studies, University of Oslo, 2007.

${ }^{[51]}$ Interview with al-Hadi Association (al-Mabarrat's branch), Tariq al-Matar, Beirut, October 29, 2012.

${ }^{[52]}$ Haret Hreik, January 18, 2012. 
${ }^{[53]}$ Interview with Mohammed Bassam, Tyre, October 8, 2012.

${ }^{[54]}$ Imam as-Sadr Foundation, Tyre, October 8, 2012.

${ }^{[55]}$ It is interesting to notice that some local development projects fail for cultural reasons, according to Bassam (i.e. Lebanese Shi'a women trained for entering the hoteling market and unlikely to follow up with the acquired skills). Or, again, foreign models are sometimes not ideal for targeting the local nuances of human vulnerability.

[56] Imam as-Sadr Foundation, Tyre, October 8, 2012.

${ }^{[57]}$ Interview with Mohammed Bassam, Tyre, October 8, 2012. In this respect, it is interesting to notice that communal tensions were discussed as more likely among aid providers than aid recipients.

${ }^{[58]}$ The return has often been criticised as too hastened by scholars and scientists, as the living conditions could not be restored in a short time. Sulphur levels, for instance, were much higher in the air than before the reconstruction process (Farah el-Jam Makkouk, Assessment of Airborne Particulate Matter Elevation in Haret Hreik (Beirut) after the Israeli Bombardment of July 2006, MA Thesis, Beirut, Lebanon, AUB, 2008, p. 72). 
${ }^{[59]}$ Interview with Amel Association conducted in Wata al-Mossaitbeh, Beirut, October 11, 2011.

${ }^{[60]}$ Interview with Amel Association conducted in Wata al-Mossaitbeh, Beirut, October 11, 2011.

${ }^{[61]}$ Interview with Mr Kamel Mohanna conducted at the Amel Association headquarter: Wata elMossaitbe, Beirut, October 24, 2011.

${ }^{[62]}$ Leader of the Education Committee of Bourj al-Barajneh. Municipality Bulletin 2013.

${ }^{[63]}$ It is also interesting to note that the term martius in ancient Greek means "witness", where, therefore, a sense of agency is totally maintained despite the suffering and the humiliation that war causes.

${ }^{[64]}$ October 19, 2011.

${ }^{[65]}$ In Haret Hreik, for example, I met wholesalers who used to donate part of the items they used to purchase to the local needy, rather than selling them on the retail market. 
S66] Saree Makdisi, "Laying Claim to Beirut: Urban Narrative and Spatial Identity in the Age of Solidère", Critical Inquiry, Vol. 23, No. 3, 1997, pp. 664-705.

[67] I am using here "z" and "y" to refer to two religious communities in Lebanon. I do not deem it necessary to specify which communities were involved in the event.

${ }^{[68]}$ Interview with a Lebanese social worker, Sin el-Fil, October 18, 2011.

${ }^{[69]}$ Fassin, Didier. 2009. "Les économies morales revisitées." Annales HSS 6: 1237-1266.

[70] Interview conducted with an American NGO worker in Mar Mikhael Annahr, Beirut, February 21, 2012.

${ }^{[71]}$ Samir Khalaf, Heart of Beirut: reclaiming the Bourj, London, UK, Saqi Books, 2006, p. 120.

${ }^{[2]}$ And this is the most common opinion that faith-based and secular aid providers who had worked in harb tammuz used to have about Lebanon. Confessional provision of services is in fact seen as an unavoidable reflection of Lebanese confessional society. Interview with a UNDP officer, Beirut Downtown, November 24, 2011. 
${ }^{[73]}$ UNDP, Guidelines on Engaging with Faith-Based Organizations and Religious Leaders, October 2014, available at:

http://www.undp.org/content/dam/undp/documents/partners/2014_UNDP Guidelines-on-Engaging-withFBOs-and-Religious-Leaders_EN.pdf [Last accessed July 14, 2016]. 